\title{
Perbandingan Suction Potential dan Water Content pada Saluran Irigasi Menggunakan Dual Reciprocity
}

\author{
Jahring*1, Nasruddin ${ }^{2}$ \\ ${ }^{1,2}$ Universitas Sembilanbelas November Kolaka \\ e-mail: ${ }^{1}$ jahring.usn@gmail.com, ${ }^{2}$ nash.math@gmail.com
}

\begin{abstract}
Abstrak
Penelitian membahas penerapan metode elemen batas dual-reciprocity (MEBDR) pada saluran irigasi jalur yang periodik pada tanah homogen. MEBDR merupakan salah metode numerik yang dapat menyelesaikan masalah infiltrasi stasioner pada saluran periodik pada tanah yang homogen. Beberapa penelitian sebelumnya hanya menhitung secara analisis. Oleh karena itu, MEBDR ini sangat diperlukan. Penelitian ini meruapakn penelitian studi literatur dengan menggunakan simulasi MATLAB. Dalam peneyelesaiannya dibangun dari Persamaan Richards. Persamaan Richards ini kemudian ditransformasikan menjadi Persamaan Helmholtz termodifikasi. Selanjutnya dengan DRBEM, solusi numerik dari Persamaan Helmholtz termodifikasi diperoleh. Menggunakan solusi numerik yang diperoleh, dapat dihitung nilai numerik dari suction potential dan water content. Dari beberapa saluran periodik, diperoleh saluran non-flat tanpa lapisan memiliki infiltrasi yang baik dibanding saluran flat dan non flat dengan lapisan impermeabel. Dalam hal ini saluran rectangular memiliki suction potential dan water content paling baik jika dibandingkan dengan trapezoidal dan semi circular. Karena perbedaan dari ketiga saluran tersebut tidak begitu signifikan. Jika diterapkan dalam bidang pertanian, maka akan membantu dalam meningkatkan hasil pertanian, khususnya tanaman yang menggunakan irigasi jalur.
\end{abstract}

Kata kunci: Infiltrasi, saluran periodik, metode elemen batas, dual reciprocity, irigasi jalur, suction potential, water content

\section{PENDAHULUAN}

Air merupakan unsur yang sangat diperlukan oleh tanaman dan segala hal yang berkaitan dengan kegiatan pertanian. Dengan ketersediaan air yang cukup dapat menjadi faktor pendukung meningkatnya hasil pertanian. Namun tidak dapat dipungkiri, tidak setiap daerah atau lahan pertanian memiliki ketersediaan air yang cukup. Hal itu disebabkan oleh curah hujan yang rendah sehingga akan sangat sulit untuk memenuhi kebutuhan air tanaman. Berkaitan dengan hal tersebut di atas, sistem irigasi dipandang perlu untuk mengatasi masalah lahan pertanian dengan intensitas air yang kurang. Adanya sistem irigasi diharapkan dapat mempertahankan tingkat kadar air yang cukup tinggi dalam tanah sehingga akar tanaman dapat mengekstrak air dari tanah secara efisien.

Penelitian ini merupakan penelitian berkelanjutan yang dilakukan oleh peneliti dengan menambahkan beberapa saluran irigasi jalur disetiap penelitian. Penelitian Jahring (2016) tentang penerapan metode elemen batas dual-reciprocity pada saluran irigasi jalur dengan saluran yang dilengkapi dengan lapisan impermeabel, yaitu trapezoidal dan rectangular dengan lapisan impermeabel, kemudian penelitian Jahring (2018) dilanjutkan dengan menambahkan saluran trapezoidal dan rectangular tanpa lapisan impermeabel. Namun pada kenyataannya bahwa saluran yang ada di lapangan tidak hanya saluran trapezoidal dan rectangular dengan dan atau tanpa lapisan impermeabel, tetapi juga terdapat saluran irigasi jalur tanpa lapisan impermeabel yang lain yaitu saluran semi circular dan sebagai pembanding ditambahkan suatu saluran flat. Oleh karena itu, dalam penelitian ini akan mengembangkan penelitian sebelumnya dengan menambahkan saluran irigasi jalur 
non-flat semi circular dan saluran flat yang dirangkum dalam satu judul "Penerapan Metode Elemen Batas Dual Reciprocity (MEBDR) pada Saluran Irigasi Jalur pada tanah homogen".

\section{METODE PENELITIAN}

\subsection{Formulasi Masalah}

Berikut akan diberikan formulasi masalah infiltrasi dari berbagai saluran-saluran irigasi jalur yang berbeda pada tanah yang homogen, yaitu:

a. Saluran flat

b. Saluran semi circular

c. Saluran rectangular dengan dan tanpa lapisan impermeabel

d. Saluran trapezoidal dengan dan tanpa lapisan impermeabel.

Selanjutnya akan ditentukan domain dari masing-masing saluran irigasi di atas. Dalam menentukan domain saluran irigasi, perlu diberikan asumsi-asumsi tertentu yaitu:

a. Panjang penampang masing-masing saluran irigasi adalah sama yaitu $2 L$

b. Saluran sangat panjang

c. Jarak antar saluran adalah sama yaitu $2 D$, atau jarak antar titik tengah saluran adalah sama yaitu $2(L+D)$

d. Saluran selalu dipenuhi air

e. Infiltrasi pada permukaan saluran irigasi konstan yaitu $v_{0}$

f. Tidak ada infiltrasi pada permukaan tanah di luar saluran irigasi

g. Tidak ada infiltrasi pada permukaan saluran impermeabel.
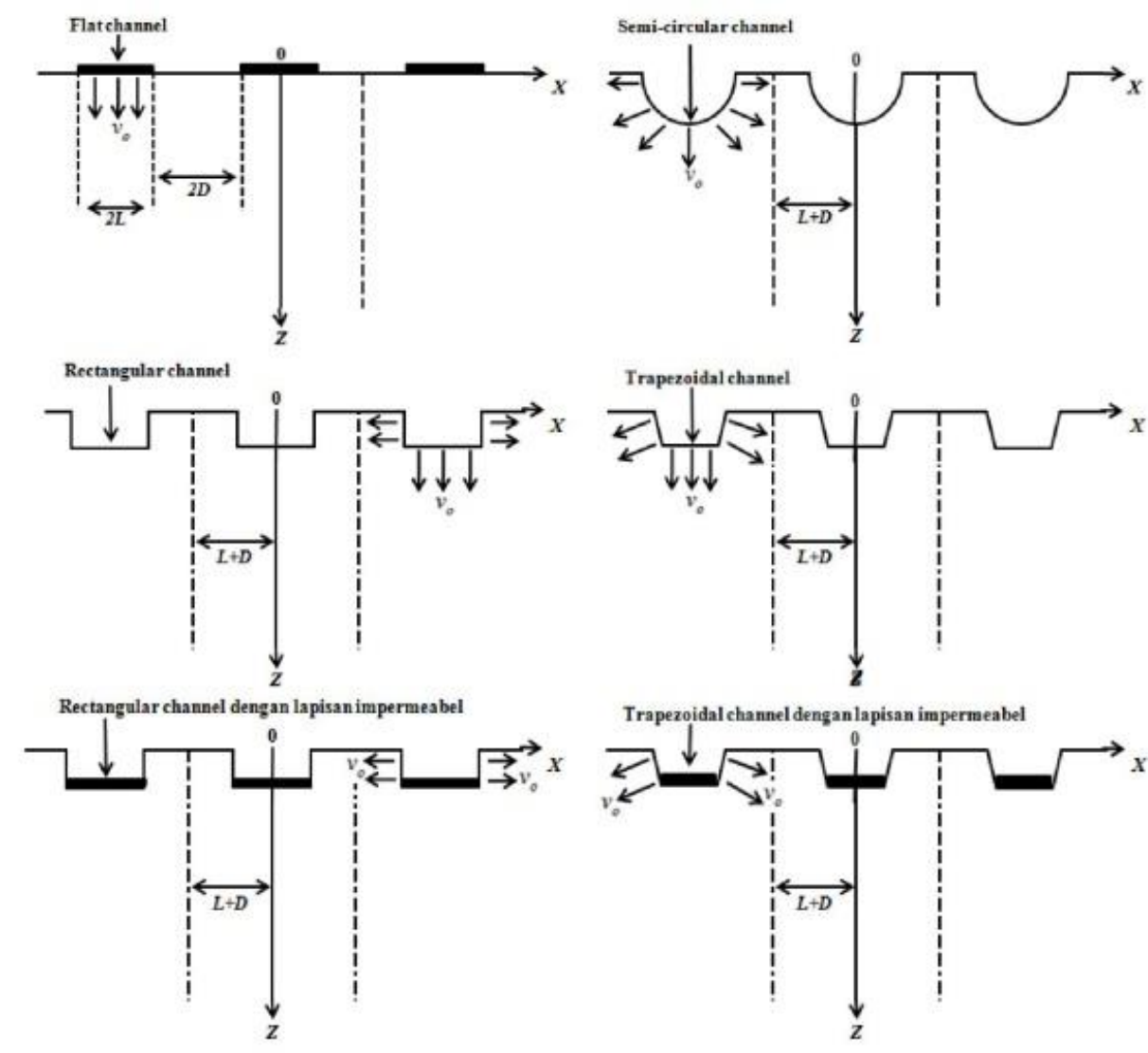

Gambar 1. Saluran Irigasi Jalur (Solekhuddin, 2013 dan Lobo, 2008) 
Dengan sifat simetris, dapat didefinisikan domain yaitu $0 \leq X \leq L+D$ dan $Z \geq 0$ yang dinyatakan dengan $R$ dengan batas $C$, dan tidak ada fluks pada $X=0$ dan $X=L+D$.

\subsection{Persamaan Fundamental}

Menurut Azis (2003), untuk masalah infiltrasi stasioner, persamaan yang sering digunakan adalah persamaan Richards, yang merupakan persamaan differensial parsial non linear yang merepresentasikan perpindahan air dalam tanah tak jenuh dalam dua dimensi adalah:

$$
\frac{\partial}{\partial X}\left(K \frac{\partial \psi}{\partial X}\right)+\frac{\partial}{\partial Z}\left(K \frac{\partial \psi}{\partial Z}\right)=\frac{\partial K}{\partial Z}
$$

dengan $K$ adalah konduktivitas hidrolik tanah tak jenuh dan $Z>0$ mengarah ke bawah secara vertical. Dalam makalah yang sama menjelaskan potensial fluks matrik $\Theta$ dihubungkan dengan konduktivitas hidrolik oleh Persamaan

$$
\Theta=\int_{-\infty}^{\psi} K(q) d q
$$

Hubungan antara konduktivitas hidrolik $K$ dari tanah tak jenuh (unsaturated soil) dan konduktivitas hidrolik $\mathrm{K}_{0}$ dari tanah jenuh (saturated soil) didefinisikan sebagai

$$
K=K_{0} e^{\alpha \psi}, \alpha>0
$$

dengan $\psi$ adalah suction potential dan $\alpha$ adalah suatu konstanta empiris.

Menggunakan Persamaan (2) dan (3) diperoleh bentuk linear dari Persamaan (1) yaitu

$$
\frac{\partial^{2} \Theta}{\partial X^{2}}+\frac{\partial^{2} \Theta}{\partial Z^{2}}=\alpha \frac{\partial \Theta}{\partial Z}
$$

Komponen fluks ke arah horizontal dan vertikal adalah

$$
U=-\frac{\partial \Theta}{\partial X}, \text { dan } V=\alpha \Theta-\frac{\partial \Theta}{\partial Z}
$$

Fluks normal pada permukaan tanah dengan vektor normal terhadap batas domain yang mengarah keluar domain dengan $n=\left(n_{1}, n_{2}\right)$ diberikan oleh

$$
F=-\frac{\partial \Theta}{\partial X} n_{1}+\left(\alpha \Theta-\frac{\partial \Theta}{\partial Z}\right) n_{2}
$$

Didefinisikan peubah-peubah tak berdimensi sebagai berikut

$$
x=\frac{\alpha}{2} X ; z=\frac{\alpha}{2} Z ; \Phi=\frac{\pi \Theta}{v_{0} L} ; u=\frac{2 \pi}{v_{0} \alpha L} U ; v=\frac{2 \pi}{v_{0} \alpha L} V ; f=\frac{2 \pi}{v_{0} \alpha L} F
$$

dan mensubstitusikan $\Phi=\phi e^{z}$ ke Persamaan (4) diperoleh suatu Persamaan berbentuk Persamaan Helmholtz termodifikasi, yaitu

$$
\frac{\partial^{2} \phi}{\partial x^{2}}+\frac{\partial^{2} \phi}{\partial z^{2}}=\phi
$$

Fluks tak berdimensi diperoleh

$$
\frac{\partial \phi}{\partial n}=\phi n_{2}-f e^{-z}
$$

Fluks pada permukaan saluran adalah $v_{0}$ dan besar fluks tak berdimensi adalah $2 \pi / \alpha L$. Sehingga syarat batas pada permukaan saluran permeabel adalah

$$
\frac{\partial \phi}{\partial n}=\frac{2 \pi}{\alpha L} e^{-z}+\phi n_{2} .
$$

Metode elemen batas Dual Reciprocity (MEBDR) digunakan untuk mencari solusi numerik Persamaan (8). Pada tahap selanjutnya, mencari solusi numerik dengan MEBDR dibutuhkan suatu Persamaan integral yang disebut Persamaan integral batas (Boundary integral equation) yaitu 
https://jurnal.unsulbar.ac.id/index.php/saintifik

$$
\lambda(\xi, \eta) \phi(\xi, \eta)=\iint_{C}\left[\phi(x, z) \frac{\partial \Phi(x, z ; \xi, \eta)}{\partial n}-\Phi(x, z ; \xi, \eta) \frac{\partial \phi(x, z)}{\partial n}\right] d s(x, z)+\iint_{R} \Phi(x, z ; \xi, \eta) \phi(x, z) d x d z,
$$

dengan solusi fundamental persamaan Laplace dua dimensi

$$
\Phi(x, z ; \xi, \eta)=\frac{1}{2 \pi} \ln \sqrt{\left[(x-\xi)^{2}+(z-\eta)^{2}\right]}
$$

dan

$$
\lambda(\xi, \eta)= \begin{cases}0, & \text { Jika }(\xi, \eta) \notin R \cup C \\ \frac{1}{2}, & \text { Jika }(\xi, \eta) \text { berada pada bagian smooth kurva } C \\ 1, & \text { Jika }(\xi, \eta) \in R .\end{cases}
$$

Persamaan integral (11) dapat diselesaikan secara numerik dengan mendiskritisasi batas domain menggunakan ruas-ruas garis yang berhubungan satu sama lain dengan ujung-ujungnya terletak pada kurva $C$ dan mendiskritisasi domain dengan titik kolokasi interior. Misalkan ruas-ruas garis tersebut $C^{(k)}, k=1,2, \ldots, N$ sehingga jumlah ruas garis sebanyak $N$ ruas garis. Pada setiap $C^{(k)}, k=1,2, \ldots, N$, dipilih titik tengahnya sebagai titik kolokasi (collocation points) yang dituliskan dengan $\left(a^{(1)}, b^{(1)}\right),\left(a^{(2)}, b^{(2)}\right), \ldots,\left(a^{(N)}, b^{(N)}\right)$ dan titik-titk kolokasi interior (interior points collocation) sebanyak $L$ titik yang dapat dituliskan dengan $\left(a^{(N+1)}, b^{(N+1)}\right), \ldots,\left(a^{(N+L)}, b^{(N+L)}\right)$. Misalkan $(\xi, \eta)=\left(x^{(n)}, y^{(n)}\right)$ untuk $n=1,2, \ldots, N+L$, maka aproksimasi dapat dituliskan sebagai

$$
\lambda\left(x^{(n)}, y^{(n)}\right) \phi^{(n)}=\sum_{j=1}^{N+L} \mu^{(n j)}+\sum_{k=1}^{N}\left(\phi^{(k)} F_{2}^{(k)}\left(x^{(n)}, y^{(n)}\right)-p^{(k)} F_{1}^{(k)}\left(x^{(n)}, y^{(n)}\right)\right)
$$

dengan $\phi^{(n)}=\left(x^{(n)}, y^{(n)}\right)(n=1,2, \ldots, N+L)$ dan

$$
\begin{gathered}
\mu^{(n j)}=\sum_{m=1}^{N+L} \omega^{(m j)} \Psi\left(x^{(n)}, y^{(n)} ; x^{(m)}, y^{(m)}\right), \\
F_{1}^{(k)}(\xi, \eta)=\int_{C^{(k)}} \Phi(x, z ; \xi, \eta) d s(x, z), \\
F_{2}^{(k)}(\xi, \eta)=\int_{C^{(k)}}\left[\frac{\partial \Phi(x, z ; \xi, \eta)}{\partial n}\right] d s(x, z) .
\end{gathered}
$$

dan

$$
\begin{gathered}
\Psi(\xi, \eta ; a, b)=\lambda(\xi, \eta) \chi(x, y ; a, b)+\sum_{k=1}^{N}\left[n_{x}^{(k)} \frac{\partial \chi(x, y ; a, b)}{\partial x}+n_{y}^{(k)} \frac{\partial \chi(x, y ; a, b)}{\partial y}\right]_{(x, y)=\left(x^{(k)}, y^{(k)}\right)} \\
F_{1}^{(k)}(\xi, \eta)-\sum_{k=1}^{N} \chi\left(x^{(k)}, y^{(k)} ; a, b\right) F_{2}^{(k)}(\xi, \eta) . \\
\omega^{(m)}=\left[\rho\left(x^{(j)}, y^{(j)} ; x^{(m)}, y^{(m)}\right)\right]^{-1}
\end{gathered}
$$

dengan

$$
\begin{aligned}
& \rho\left(x, z ; a^{(m)}, b^{(m)}\right)=1+r^{2}\left(x, z ; a^{(m)}, b^{(m)}\right)+r^{3}\left(x, z ; a^{(m)}, b^{(m)}\right), \\
& \chi\left(x, z ; a^{(m)}, b^{(m)}\right)=\frac{1}{4} r^{2}\left(x, z ; a^{(m)}, b^{(m)}\right)+\frac{1}{16} r^{4}\left(x, z ; a^{(m)}, b^{(m)}\right)+\frac{1}{25} r^{5}\left(x, z ; a^{(m)}, b^{(m)}\right), \\
& r\left(x, z ; a^{(m)}, b^{(m)}\right)=\sqrt{\left(x-a^{(m)}\right)^{2}+\left(z-b^{(m)}\right)^{2}} .
\end{aligned}
$$

MEBDR digunakan untuk memperoleh solusi numerik $(\phi)$, dan menggunakan Persamaan berikut untuk memperoleh suction potential ( $\psi$ ), (Jahring, 2016).

$$
\psi=\frac{1}{\alpha} \ln \left(\frac{\alpha v_{0} L \phi e^{z}}{\pi K_{0}}\right) .
$$


https://jurnal.unsulbar.ac.id/index.php/saintifik

Untuk memperoleh water content $(\theta)$ digunakan Persamaan (Warrick, 2001)

$$
\frac{\theta-\theta_{r}}{\theta_{s}-\theta_{r}}=\left[\frac{1}{1+(\alpha \psi)^{n}}\right]^{m}
$$

dengan $\theta_{r}$ dan $\theta_{s}$ adalah water content residual dan jenuh, $\alpha, n$ dan $m=1-(1 / n)$ adalah parameter yang bergantung pada jenis tanah.

\section{HASIL DAN PEMBAHASAN}

MEBDR diterapkan pada masalah infiltrasi stasioner pada beberapa saluran periodik yang berbedabeda pada tanah homogen dan dipilih jenis tanah Pima clay loam (PCL) dengan nilai $\alpha$ dan $K_{0}$ masing-masing $0.014 \mathrm{~cm}^{-1}$ dan $9.9 \mathrm{~cm} /$ hari (Jahring, 2016), (Lobo, 2008), (Solekhuddin, 2013), $\theta_{r}=0.095 \mathrm{~cm}^{-1}, \theta_{s}=0.41 \mathrm{~cm}^{-}$ ${ }^{1}$ dan $n=1,31 \mathrm{~cm}^{-1}$ (Warrick, 2001), dan nilai $v_{0}$ adalah $75 \%$ dari nilai $K_{0}$ (Basha, 1999). Selanjutnya ukuran dari tiap-tiap saluran non-flat impermeabel dapat dipilih sedemikian sehingga panjang permukaan saluran sama yaitu $L=50 \mathrm{~cm}$ dan $D=50 \mathrm{~cm}$. Menggunakan nilai $L$ tersebut, maka lebar saluran non-flat adalah $200 / \pi$ $\mathrm{cm}$ dengan kedalaman $(50-100 / \pi) \mathrm{cm}$ untuk saluran rectangular, $75 / \pi \mathrm{cm}$ untuk saluran trapezoidal, serta masing-masing $50 \mathrm{~cm}$ dan $49.5625 \mathrm{~cm}$ untuk saluran rectangular dan trapezoidal dengan lapisan impermeabel. Selanjutnya MEBDR diimplementasikan dalam bahasa pemrograman MATLAB.

Pada MEBDR banyaknya segmen garis $(N)$ dan titik interior $(M)$ berpengaruh terhadap keakuratan solusi numerik yang dihasilkan. Berikut diberikan jumlah segmen garis dan titik interior, (Jahring, 2016).

1. Saluran flat diberikan $N=200$ dan $M=625$

2. Saluran semi circular diberikan $N=201$ dan $M=620$

3. Saluran rectangular diberikan $N=203$ dan $M=625$

4. Saluran trapezoidal diberikan $N=202$ dan $M=619$

5. Saluran rectangular impermeabel diberikan $N=208$ dan $M=609$

6. Saluran trapezoidal impermeabel diberikan $N=209$ dan $M=609$

Selanjutnya variasi nilai $\psi$ dan $\theta$ dengan kedalaman $(Z)$ pada jarak yang berbeda-beda dari pusat saluran $(X)$ secara geometri dapat dilihat pada Gambar 2-6 berikut ini.
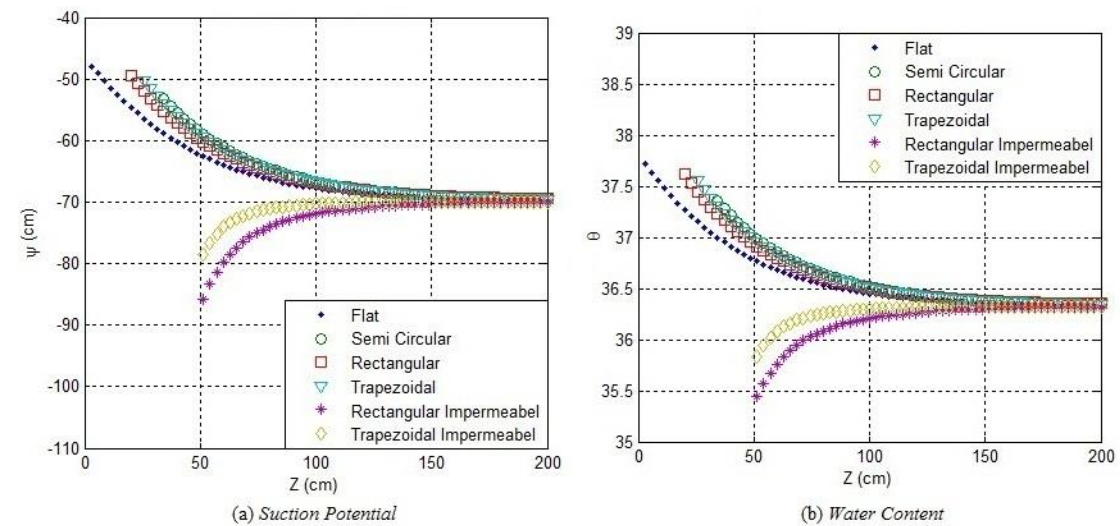

Gambar 2. Suction potential dan water content pada $X=15$

Dari Gambar 2(a) yaitu pada $X=15$ yang terletak di bawah saluran, nilai $\psi$ untuk semua jenis saluran (kecuali saluran dengan lapisan impermeabel) menurun terhadap Z. Hal ini menunjukkan bahwa kandungan air (water content) di bawah saluran pada bagian dangkal lebih besar dibandingkan pada bagian terdalam di dalam tanah sehingga perembesan air semakin ke dalam semakin kecil. Hal ini didukung dengan nilai $\theta$ yang semakin menurun (lihat Gambar 2(b)) yang menunjukkan bahwa kandungan air semakin ke bawah semakin kecil. Dari Gambar juga terlihat bahwa khusus untuk saluran dengan lapisan impermeabel, nilai $\psi$ dan 
$\theta$ meningkat. Ini disebabkan karena pada posisi $X=15$ terletak di bawah saluran yang impermeabel sehingga berdasarkan asumsi awal tidak ada infiltrasi.
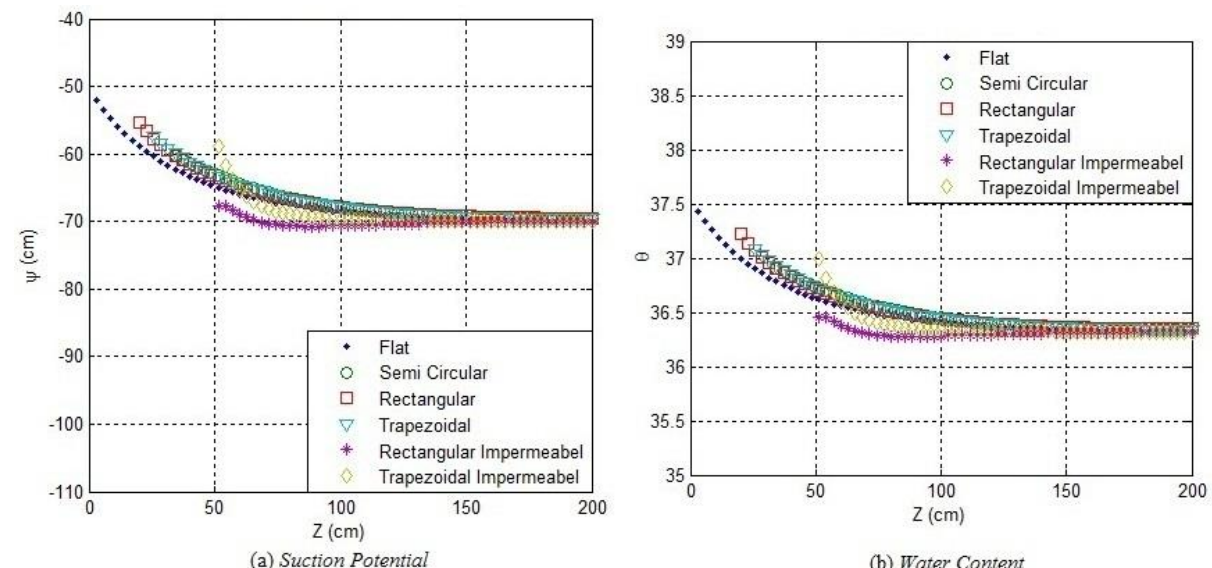

(b) Water Content

Gambar 3. Suction potential dan water content pada $X=30$

Gambar 3 di atas dengan $X=30$ juga menunjukkan penurunan nilai $\psi$ dan $\theta$ terhadap $Z$ karena masih terletak di bawah saluran. Namun ada sedikit perbedaan pada saluran dengan lapisan impermeabel. Terlihat bahwa $\psi$ dan $\theta$ meningkat. Hal ini disebabkan karena adanya lapisan impermeabel pada saluran.

Pada beberapa saluran non-flat tanpa lapisan impermeabel, tidak ada perbedaan nilai $\psi$ yang signifikan. Namun jika dibandingkan dengan saluran flat dan non flat dengan lapisan impermeabel, terdapat perbedaan nilai $\psi$ yang signifikan khususnya di bawah saluran pada bagian dangkal. Ini disebabkan oleh posisi permukaan saluran. Pada saluran flat permukaan terletak pada permukaan tanah yaitu pada $Z=0$, sedangkan kelima saluran yang lain permukaannya terletak dari $Z=0$ sampai kedalaman yang ditentukan.
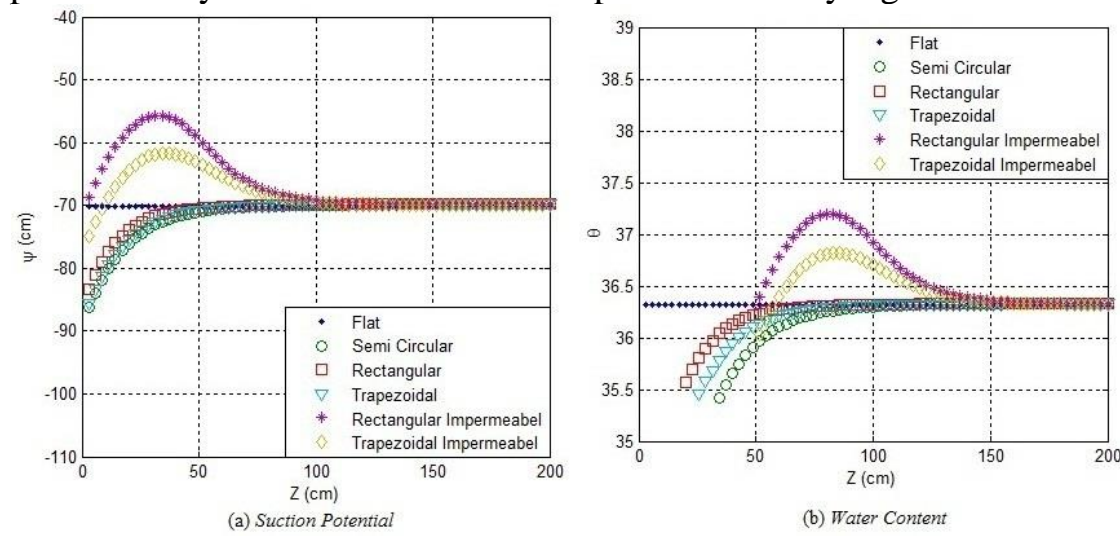

Gambar 4. Suction potential dan water content pada $X=50$

Saluran flat dengan $X=50$ pada Gambar 4 terletak pada ujung saluran dengan nilai $\psi$ dan $\theta$ yang secara grafik konstan pada nilai $\psi=-70$ dan $\theta=36$,3. Ini dikarenakan pada $X=50$ terletak antara saluran yang sebelumnya diasumsikan terdapat infiltrasi dan permukaan tanah yang sudah diasumsikan tidak ada infiltrasi sehingga nilai $\psi$ hampir konstan. Selain itu, kondisi ini menunjukkan bahwa sepanjang titik $X=50$, infiltrasi sama yang menyebabkan kandungan air sama.

Pada saluran dengan lapisan impermeabel (Gambar 4(a), 5(a), dan 6(a)) nilai $\psi$ naik pada kedalaman tertentu dan turun pada kedalaman tertentu juga menuju ke konvergenannya. Ini menunjukkan bahwa pada bagian dangkal sampai kedalaman tertentu di bawah permukaan tanah, kandungan air lebih rendah dari bagian yang lebih dalam. Hal ini disebabkan oleh panjang saluran yang dialiri air cukup panjang sehingga menyebabkan adanya aliran air horizontal yang sangat besar pada saluran yang mempengaruhi kandungan air di bawah permukaan tanah di luar saluran. Sehingga grafik nilai $\psi$ dan $\theta$ naik dari permukaan tanah sampai pada kedalaman yang dipengaruhi aliran air horizontal. Selanjutnya grafik akan turun sampai menuju ke 
konvergenannya yang dipengaruhi oleh infiltrasi yang ada di sekitar saluran. Hal ini diperjelas pada Gambar 4(b), 5(b), dan 6(b) dengan nilai $\theta$ yang naik turun hingga menuju kekonvergenannya.

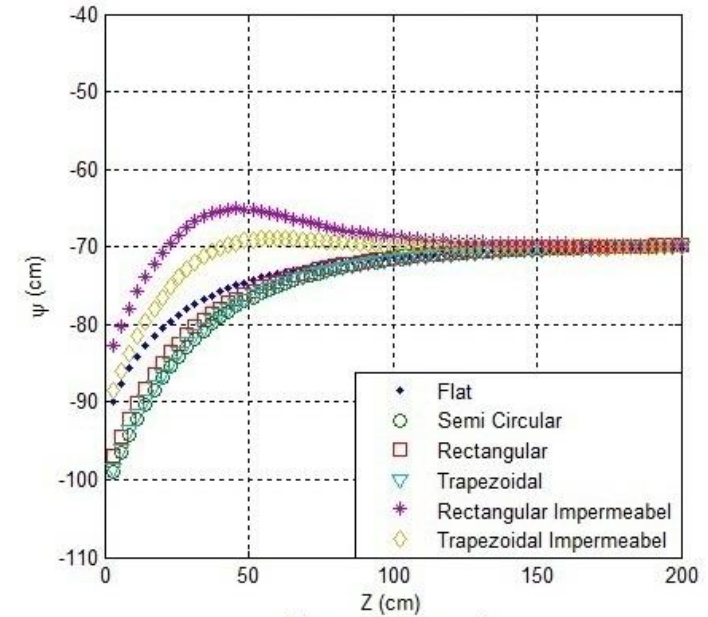

(a) Suction Potential

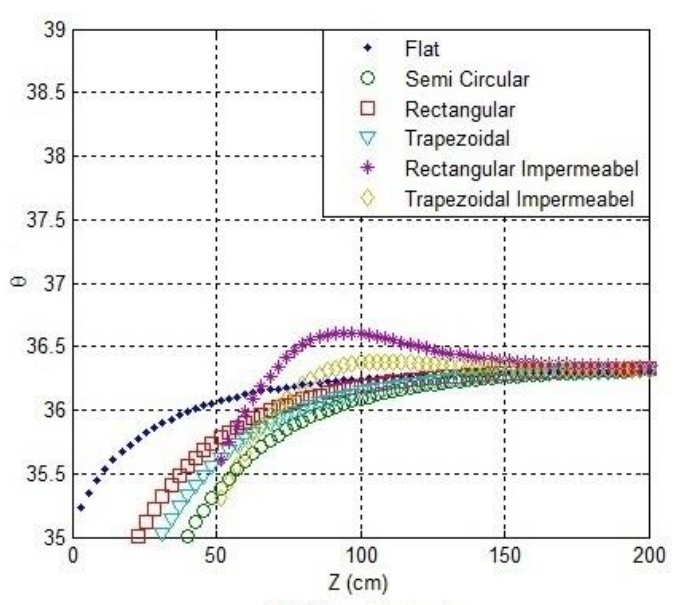

(b) Water Content

Gambar 5. Suction potential dan water content pada $X=65$

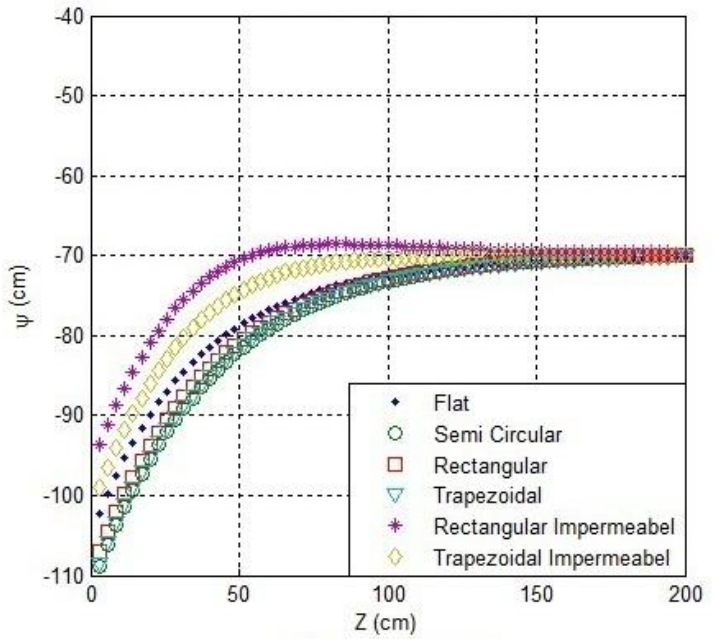

(a) Suction Potential

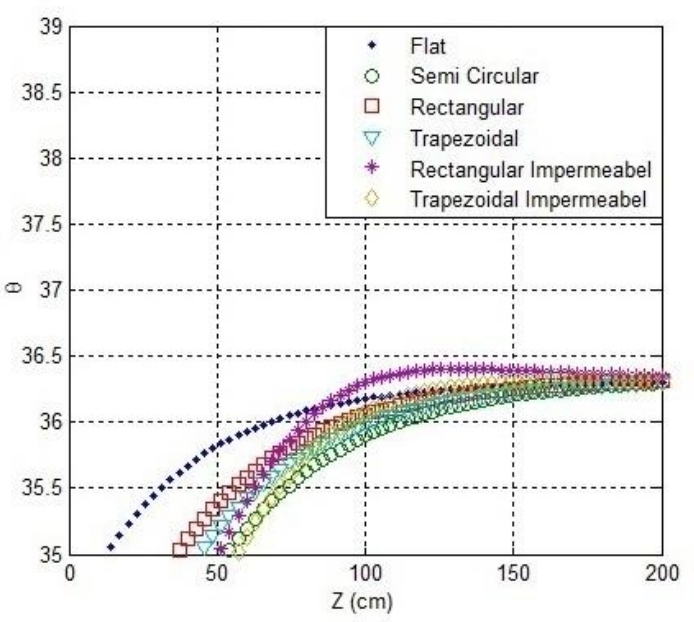

(b) Water Content

Gambar 6. Suction potential dan water content pada $X=85$

Pada $X=65$ dan $X=85$, nilai $\psi$ meningkat terhadap $Z$ (Gambar 5(a) dan 6(a). Hal ini menunjukkan bahwa kandungan air (water content) pada permukaan tanah paling rendah dibandingkan pada semua bagian tanah di dalam domain. hal ini juga ditunjukkan pada Gambar 5(b) dan 6(b) dengan nilai $\theta$ yang semakin meningkat. Ini karena adanya asumsi awal bahwa pada permukaan tanah di luar saluran tidak ada aliran air yang masuk ke dalam tanah. Pada beberapa saluran non-flat tanpa lapisan impermeabel, tidak ada perbedaan nilai $\psi$ dan $\theta$ yang signifikan. Namun jika dibandingkan dengan saluran flat dan non-flat dengan lapisan impermeabel, terdapat perbedaan nilai $\psi$ dan $\theta$ di luar saluran.

Dari Gambar 2 -.6 dapat dijelaskan bahwa hubungan antara suction potential $(\psi)$ dan water content $(\theta)$ pada jenis tanah Pima Clay Loam (PCL) adalah berbanding lurus. Dengan kata lain, semakin besar infiltrasi maka semakin besar pula kandungan airnya. Perhatikan saluran flat pada Gambar 2(a) - 6(a). Dari hasil yang diberikan, saluran flat memiliki infiltrasi dan kandungan air paling besar. Namun pada realisasinya, saluran flat tidak mungkin untuk diterapkan dengan asumsi-asumsi yang telah diberikan sebelumnya. Hal ini dikarenakan sejatinya saluran flat tidak ada, hanya bisa diselesaikan secara analitik saja tanpa bisa diterapkan. 
Selanjutnya perhatikan pula saluran non-flat tanpa lapisan impermeabel (semi circular, rectangular dan trapezoidal) pada Gambar 2(a) - 6(a). Pada Gambar tersebut terlihat bahwa saluran rectangular memiliki infiltrasi paling baik jika dibandingkan dengan semi circular dan trapezoidal. Hal ini dikarenakan nilai suction potential di bawah saluran pada bagian dangkal paling besar dan nilai suction potential di bawah permukaan tanah di luar saluran pada bagian dangkal paling kecil. Namun karena perbedaan nilai suction potential dari ketiga saluran tersebut tidak begitu signifikan, sehingga hanya diberikan distribusi nilai $\psi$ untuk satu saluran saja.

Jika dipandang dari segi aplikatif, di Indonesia banyak dijumpai saluran-saluran dengan bentuk trapezoidal baik itu diperoleh dari internet ataupun dari sumber informasi yang lain. Hal ini disebabkan oleh selain cara membuat salurannya sangat mudah, juga memiliki nilai suction potential dan water content paling baik diantara saluran yang lain. Oleh karena itu, untuk saluran periodik non-flat dengan dan tanpa lapisan impermeabel hanya akan diberikan distribusi nilai $\psi$ pada saluran trapezoidal, dengan anggapan bahwa secara umum infiltrasi dari setiap saluran dengan saluran yang lain dapat dianggap sama. Secara geometri distribusi nilai $\psi$ disajikan pada Gambar 7 berikut ini.

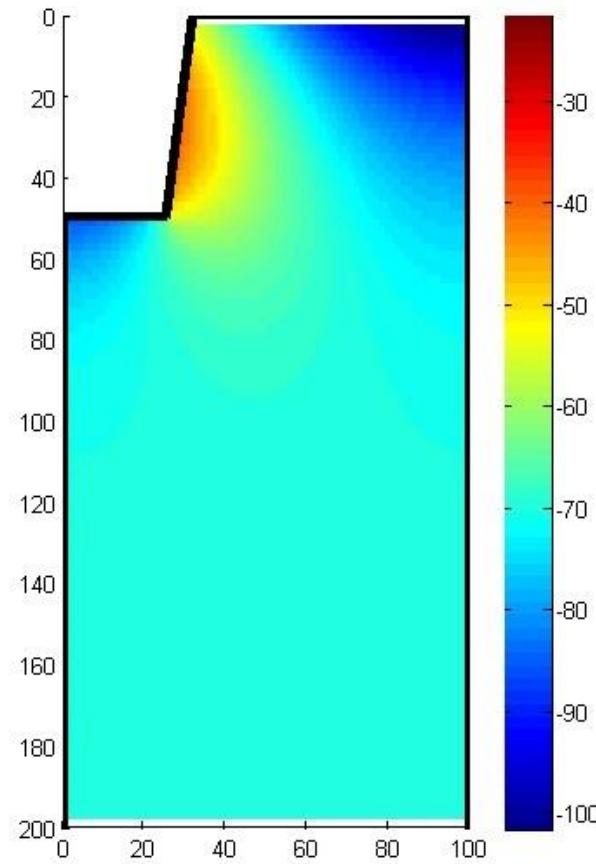

(a) Trapezoidal dengan Lapisan Impermeabel

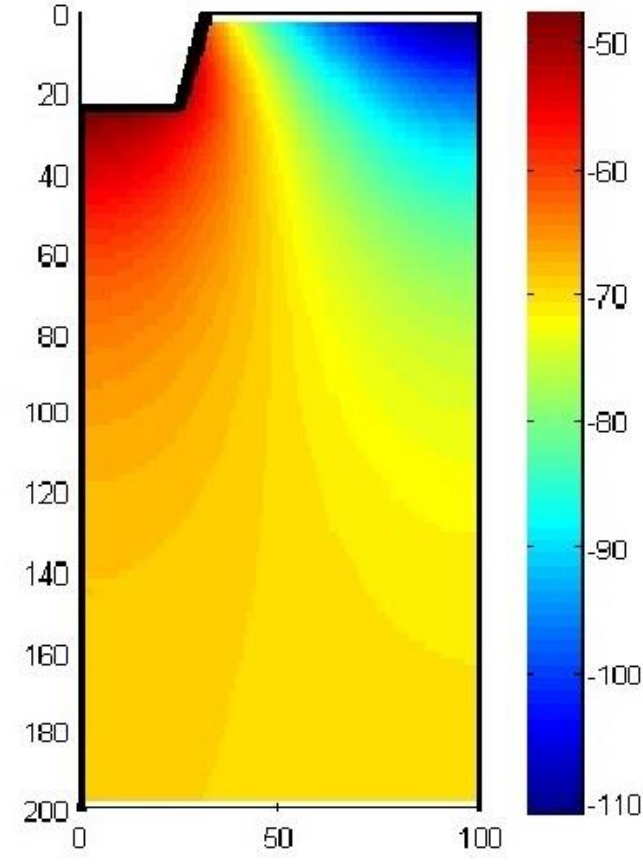

(b) Trapezoidal tanpa Lapisan Impermeabel

Gambar 7. Surface plot distribusi nilai $\psi$ pada saluran trapezoidal

Dari Gambar 7(a) di atas, terlihat jelas distribusi nilai $\psi$. Pada bagian dangkal di bawah permukaan saluran memiliki nilai $\psi$ paling besar di antara bagian yang lain dan terus menurun menuju ke titik kekonvergenannya. Ini menunjukkan bahwa kandungan air (water content) di bawah permukaan saluran paling besar dibandingkan dengan bagian lain. Pada bagian di bawah permukaan tanah di luar saluran yang tidak jauh dari saluran terlihat semua nilai $\psi$ hampir sama. Ini menunjukkan bahwa kandungan air (water content) hampir sama pada semua bagian kedalaman tanah. Selanjutnya pada bagian di bawah permukaan tanah di luar saluran yang merupakan titik terjauh dari pusat saluran dan di bawah permukaan saluran impermeabel memiliki nilai $\psi$ yang paling rendah dibandingkan dengan bagian yang lain dan terus meningkat menuju titik kekonvergenannya pada kedalaman tertentu. Hal ini menunjukkan bahwa di bawah permukaan tanah di luar saluran pada posisi jauh dari pusat saluran dan di bawah permukaan saluran impermeabel memiliki kandungan air (water content) paling rendah dibandingkan dengan bagian tanah yang lain dalam domain.

Dari Gambar 7(b) di atas terlihat jelas distribusi nilai $\psi$. Pada bagian dangkal di bawah permukaan saluran memiliki nilai $\psi$ paling besar di antara bagian yang lain dan terus menurun menuju ke titik 
https://jurnal.unsulbar.ac.id/index.php/saintifik

kekonvergenannya. Ini menunjukkan bahwa kandungan air (water content) di bawah permukaan saluran paling besar dibandingkan dengan bagian lain. Pada bagian di bawah permukaan tanah di luar saluran yang tidak jauh dari saluran terlihat semua nilai $\psi$ hampir sama. Ini menunjukkan bahwa kandungan air (water content) hampir sama pada semua bagian kedalaman tanah. Selanjutnya pada bagian di bawah permukaan tanah di luar saluran yang merupakan titik terjauh dari pusat saluran memiliki nilai $\psi$ yang paling rendah dibandingkan dengan bagian yang lain dan terus meningkat menuju titik ke konvergenannya pada kedalaman tertentu. Hal ini menunjukkan bahwa di bawah permukaan tanah di luar saluran pada posisi jauh dari pusat saluran memiliki kandungan air (water content) paling rendah dibandingkan dengan bagian tanah yang lain dalam domain.

\section{KESIMPULAN}

Berdasarkan hasil dan pembahasan, maka dapat disimpulkan bahwa Suction potential pada semua jenis saluran paling besar terletak pada domain di bawah permukaan saluran pada bagian dangkal. Ini menunjukkan bahwa water content pada bagian dangkal di bawah permukaan saluran lebih tinggi dari bagian terdalam pada domain di dalam tanah. Suction potential pada semua jenis saluran paling kecil terletak pada domain di bawah permukaan tanah di luar saluran pada bagian dangkal. Ini menunjukkan bahwa water content pada bagian dangkal di bawah permukaan tanah di luar saluran paling rendah dari pada bagian domain yang lain di dalam tanah. Terdapat perbedaan nilai $\psi$ yang signifikan antara saluran flat dengan saluran non flat baik tanpa maupun dengan lapisan impermeabel. Pada jenis tanah pima clay loam (PCL), suction potential berbanding lurus terhadap water content. Artinya, semakin besar infiltrasi maka semakin besar pula kandungan airnya.

\section{DAFTAR PUSTAKA}

Azis, M.I., Clements, D.L., Lobo, M., 2003, A Boundary Element Method for Steady Infiltration from Periodic Channels, ANZIAM J. 44:C61-C78.

Basha, H.A., 1999, Multidimensional Linearized Nonsteady Infiltration with Prescribed Boundary Conditions at the Soil Surface, Water Resources Research, 35(1):75-83.

Batu, V., 1977, Steady Infiltration from a Ditch; Theory and Experiment, Soil Sci, Soc, Am, j., 41:677-681.

Jahring, 2016, The Application of Dual Reciprocity Boundary Element Method for Steady Infiltration Problems in the Periodic Channel with Impermeable Layer, Journal of Math Sciences (JMS). 1.2;28-34.

Lobo, M., 2008, Boundary Element Methods for A Class of Infiltraton Problems, PhD Tesis, Adelaide University.

Solekhudin, I., Ang, K.C., 2013, A Dual-Reciprocity Boundary Element Method for Steady Infiltration Problems, ANZIAM J. 54:171-180.

Warrick, A.W., 2001, Soil Physics Companion, CRC Press LLC, Boca Raton. 